' Albrey MB, Murphy AM. Rotaviruses and acute gastroenteritis of infants and children. Med $\mathcal{f}$ Aust 1976;i:82-5.

${ }^{2}$ Chrystie IL, Totterdell BM, Banatvala JE. Asymptomatic endemic rotavirus infections in the newborn. Lancet 1978; i:1176-8.

${ }^{3}$ Bryden AS, Thouless ME, Hall CJ, et al. Rotavirus infections in a specialcare baby unit. Fournal of Infection 1982;4:43-8.

- Rodger SM, Bishop RF, Birch C, McLean B, Holmes IH. Molecular epidemiology of human rotaviruses in Melbourne, Australia, from 1973 to 1979 , as determined by electrophoresis of genome ribonucleic acid. F Clin Microbiol 1981;13:272-8.

- Dearlove J, Latham P, Dearlove B, Pearl K, Thomson A, Lewis IG. Clinical range of neonatal rotavirus gastroenteritis. $\mathrm{Br} \mathrm{Med} \mathrm{f} \mathrm{1983;286}$ 1473-5.

${ }^{6}$ Moe K, Shirley JA. The effects of relative humidity and temperature on the survival of human rotavirus in faeces. Arch Virol 1982;72:179-86.

7 Totterdell BM, Chrystie IL, Banatvala JE. Cord blood and breast-milk antibodies in neonatal rotavirus infection. $\mathrm{Br} M$ ed $\mathcal{F} 1980 ; \mathbf{2 8 0}: 282-30$.

* Sanekata ' $T$, Yoshida Y, Oda K, Okada H. Detection of rotavirus antibody by inhibition of reverse passive hemagglutination. 7 Clin Microbiol 1982 ; $15: 148-55$.

9 Mata LJ, Kronmal RA, Garcia B, Butler W, Urrutia JJ, Murillo S. Breast-feeding, weaning and the diarrhoeal syndrome in a Guatemalan Indian village. In: Acute diarrhoea in childhood. Amsterdam: Elsevier, Excerpta Medica, North Holland, 1976:311-38. (Ciba Foundation symposium (new series), No 42.)

${ }^{10}$ Flewett $\mathrm{TH}$. Clinical features of rotavirus infection. In: Tyrrell AJ, Kapikian AZ, eds. Virus infections of the gastrointestinal tract. New York Marcel Dekker, 1982:125-45.

11 Elias MM. Distribution and titres of rotavirus antibodies in different age groups. f Hyg (Lond) 1977;79:365-72.

1: Orstavik I, Haug KW, Søvde A. Rotavirus-associated gastroenteritis in two adults probably caused by virus reinfection. Scand $\mathcal{F}$ Infect Dis 1976 $8: 277-8$.

13 Cubitt WD, Holzel $\mathrm{H}$. An outbreak of rotavirus infection in a long-stay ward of a geriatric hospital. F Clin Pathol $1980 ; 33: 306-8$.

14 Sato K, Inaba Y, Miura Y, Tokuhisa S, Matumoto M. Antigenic relationships between rotaviruses from different species as studied by neutralization and immunofluorescence. Arch Virol 1982;73:45-50.

15 Zissis G, Lambert JP, Kapsenberg JG, Enders G, Mutanda LN. Human rotavirus serotypes. Lancet 1981 ; i :944-5.

is Gaul SK, Simpson TF, Woode GN, Fulton RW. Antigenic relationships among some animal rotaviruses: virus neutralization in vitro and crossprotection in piglets. $\mathcal{F}$ Clin Microbiol $1982 ; \mathbf{1 6}: 495-503$

17 Linhares AC, Pinheiro FP, Freitas RB, Gabbay YB, Shirley JA, Beards GM. An outbreak of rotavirus diarrhea among a nonimmune, isolated South American Indian community. Am f Epidemiol 1981;113:703-10.

is Kapikian AZ, Wyatt RG, Greenberg HB, et al. Approaches to immunization of infants and young children against gastroenteritis due to rotaviruses. Rev Infect Dis 1980;2:459-69.

19 Flewett TH. New prospects for control of virus diarrhoea in children. $\mathcal{F} R$ Soc Med $1982 ; 75: 493-4$.

\section{Questions on clinical trials}

In private, medical scientists will admit that therapeutic research has had a poor record over the past two decades. Far too many questions about the value of treatment that were being asked in the early 1960s remain unanswered. For rheumatologists the outstanding problem is whether any of the available drugs really do slow down the disease process in rheumatoid arthritis.

Among the reasons that that question is still unanswered are the poor design of many clinical trials and the futile planning of many medical conferences. No one gains from and much time is wasted by meetings at which speakers read boring accounts of poor studies to audiences assembled for other motives, with little if any time for discussion.

Against that background, I was pleased to attend a meeting held at the London Hospital earlier this year (and now reported in a supplement ${ }^{1}$ to the British Fournal of Rheumatology). The meeting had only a few, commendably brief papers and most of the participants' time was spent in small workshops. Furthermore, the final session produced some clear conclusions and some more general opinions.

As an editor faced each year with the task of reading and assessing dozens of clinical trials I found myself in strong agreement with Richard Peto: a good trial should ask an important question and answer it reliably. Peto, the "big wing" man of trial design, believes that most good trials need to be very large or to have a long period of treatment or bothan approach vindicated by the contrast between the inconclusive results of early, small trials of beta blockers in coronary heart disease and the clear evidence of a small but important effect that emerged from the massive later studies.

One of the main reasons that the beta blocker studies convinced the sceptics was that the measure chosen was deathas "objective" and "hard" an end point as anyone could want. Rheumatoid arthritis provides no such clear measure-indeed, as Verna Wright reminded the meeting, clinicians may all too easily spend years writing "doing well" in the notes of a patient who has become progressively more crippled before their eyes. What matters to patients is the effects on their daily life of their damaged joints, and the account by J F Fries of the Stanford Arthritis Center Health Assessment Questionnaire ${ }^{2}$ suggested that a self administered questionnaire may be one workable method of measuring the extent of an individual's disability and of repeating that assessment at intervals. Typical of the questions asked are "Are you able to open jars which have been previously opened?" and "Are you able to bend down to pick up clothing from the floor ?" When combined with a scoring system a questionnaire of this kind gives a good measure of features of practical importance to the patient. Indeed, one of the conclusions reached at the meeting was that patients should be encouraged to take more part in deciding the objectives of treatment.

So the way forward for rheumatologists seems to lie in better designed, better organised trials, probably larger and multicentre, and certainly using assessment methods that are reproducible, simple, and relevant to the patients' problems. Clinicians in other disciplines might usefully ask themselves similar questions to those posed at the London Hospital.

TONY SMITH

Deputy Editor,

$B M \mathcal{F}$

1 Chaput de Saintonge DM, Joyce CRB, Currey HLF, Kirwan JR. Advances in assessing rheumatoid arthritis. British fournal of Rheumatology $1983 ; 22$, suppl:1-97.

2 Fries JF, Spitz PW, Young DY. The dimensions of health outcomes: the health assessment questionnaire, disability and pain scales. $\mathcal{F}$ Rheumatol $1982 ; 9: 789-93$

\section{Latissimus dorsi reconstruction of the breast}

The latissimus dorsi is a large triangular muscle taking its origin from the lower thoracic and lumbar vertebrae, and from the posterior crest of the ilium. As it sweeps along the posterior wall of the axilla to be inserted into the bicipital groove of the humerus the muscle narrows considerably. The skin overlying the latissimus dorsi muscle is adequately supplied by perforating blood vessels from the muscle itself, and, conveniently for reconstructive purposes, the dominant nerve and blood supply of the muscle (the subscapular neurovascular bundle) enters its deep surface in the axilla. These anatomical features make it possible for the whole muscle origin, with an 
island of overlying skin of any size, to be mobilised as a well vascularised myocutaneous flap and rotated in an arc about the narrow tendon of insertion. This versatile myocutaneous flap may be used to reconstruct defects in the head and neck ${ }^{1}$ and the axilla and chest wall ${ }^{2}$; and its excellent blood supply makes it particularly useful for reconstruction in heavily irradiated areas. It is also eminently suitable for reconstruction of the breast after mastectomy.

The loss of body image and deformity after mastectomy together with the use of an external prosthesis may produce profound psychiatric and social consequences, whose nature and extent have been ignored until recently. At least two fifths of women after mastectomy have serious anxiety, depression, and social or sexual difficulties. ${ }^{3}$ Such results might be acceptable if routine mastectomy were indisputably the safest method of treatment of breast cancer, but convincing evidence is accumulating that equivalent local control and survival can be achieved, certainly for smaller cancers, without sacrificing the breast. Opinion is gradually changing in favour of breast conservation and radical radiotherapy. The work of Calle and others, albeit uncontrolled, has shown that when breast cancers of less than $3 \mathrm{~cm}$ in diameter are treated by wide local excision and radical radiotherapy recurrence is comparable with that after mastectomy. ${ }^{4}$ Nevertheless, the specific technique and quality of the radical radiotherapy are of the utmost importance.

Unfortunately, entrenched opinions die hard, and not all surgeons in Britain are prepared to offer treatment that conserves the breast; but with an increasingly informed population who are entitled to participate in the choice of their primary treatment, and with general practitioners who are more ready to accept the new evidence, inevitably the trend is away from routine mastectomy and towards the selection of patients for conservation of the breast. This change in pattern of primary treatment will decrease the need for later reconstruction-but for the moment there is no shortage of requests.

Several authors have described mastectomy combined with immediate reconstruction, either by an internal prosthesis alone $\mathbf{5}^{5}$ or by a prosthesis in conjunction with a rectus abdominis $^{6}$ or latissimus dorsi myocutaneous flap. In my opinion, the routine use of mastectomy and immediate reconstruction is not an alternative to conservation of the breast with radical radiotherapy. The reconstructed breast is generally aesthetically inferior to the conserved breast, and the nipple is anaesthetic, to say nothing of the greater magnitude of surgery and potential complications.

In the management of breast cancer, therefore, the most important place for the latissimus dorsi myocutaneous flap is in late reconstruction after mastectomy. The anatomical details $^{78}$ and operative techniques ${ }^{910}$ have been well described, as have details of refinements for enhancing the aesthetic appearance. ${ }^{1112}$ The final result will depend on the site of the mastectomy scar and the type of mastectomy performed. Transverse scars are more favourable than oblique scars, which in turn are better than vertical scars. The site of the skin island may be planned anywhere over the latissimus dorsi muscle and a variable amount of muscle may be included distal and lateral to the skin island, depending on the site of the scar and whether additional muscle is required to cover bare ribs or to reconstruct the anterior axillary fold. The shape of the skin island may be varied to fulfil the reconstructive requirements of the particular case, but whenever possible the line of skin closure on the back and all scars of the reconstructed breast should be included within the volume covered by the brassière. The size of the prosthesis inserted deep to the flap will depend on the size of the opposite breast and the wishes of the patient, but contralateral reduction, augmentation, or dermal mastopexy may be required. The complications associated with endoprostheses include failure to achieve symmetry, prosthetic shift or encapsulation, and infection-extrusion. Many women are satisfied with the basic reconstruction and do not request the second stage of replacement of the nipple and areola.

This technique is not bound to any specialty, and the skill can be acquired by any surgeon with enthusiasm for this work. The operation is readily available on the National Health Service.

Consultant Surgeon in Oncology,

J MEIRION ThOMAS

Westminster Hospital

London SWIP 2AP

' Quillen CG, Shearin JC Jr, Georgiade NG. Use of the latissimus dorsi myocutaneous island flap for reconstruction in the head and neck area. Plast Reconstr Surg 1978;62:113-7.

${ }^{2}$ McCraw JB, Penix JO, Baker JW. Repair of major defects of the chest wall and spine with the latissimus dorsi myocutaneous flap. Plast Reconstr Surg 1978;62:197-206.

${ }^{3}$ Maguire GP, Lee EG, Bevington DJ, Küchemann CS, Crabtree RJ Cornell CE. Psychiatric problems in the first year after mastectomy. Br Med f 1978;i:963-5.

4 Calle R. Conservative management of operable breast cancer. Ten years experience at the Foundation Curie. Cancer 1978;42:2045-53.

5 Watts GT. Reconstruction of the breast as a primary and secondary procedure following mastectomy for carcinoma. $\mathrm{Br} \mathcal{F}$ Surg 1976;63: 823-5.

${ }^{6}$ Webster DJT, Hughes LE. The rectus abdominis myocutaneous island flap in breast cancer. Br $\mathcal{F}$ Surg 1983;70:71-3.

7 Mendelson BC, Masson JK. Treatment of chronic radiation injury over the shoulder with a latissimus dorsi myocutaneous flap. Plast Reconstr Surg 1977;60:681-91.

* Maxwell GP, McGibbon BM, Hoopes JE. Vascular considerations in the use of a latissimus dorsi myocutaneous flap after a mastectomy with an axillary dissection. Plast Reconstr Surg 1979;64:771-80.

${ }^{9}$ Bostwick J, Vasconez LO, Jurkiewicz MJ. Breast reconstruction after a radical mastectomy. Plast Reconstr Surg 1978;61:682-93.

${ }^{10}$ Mendelson BC. The latissimus dorsi flap for breast reconstruction. Aust NZ F Surg 1980;50:200-4.

11 Mendelson BC. Lattissimus dorsi breast reconstruction-refinement and results. Br $\mathcal{F}$ Surg 1983;70:145-9.

${ }_{12}$ Millard DR Jr. Breast aesthetics when reconstructing with the latissimus dorsi musculocutaneous flap. Plast Reconstr Surg 1982;70:161-72. 